\title{
Impact of the Interest Drawback Programme (IDP) On Loan Repayment under the Agricultural Credit
}

\section{Guarantee Scheme (ACGS)}

\author{
Musa A. Olasupo ${ }^{1, *}$, Caroline A. Afolami ${ }^{2} \&$ Adebayo M. Shittu ${ }^{2}$ \\ ${ }^{1}$ Development Finance Office, Central Bank of Nigeria, Abeokuta. Ogun State, Nigeria \\ ${ }^{2}$ Department of Agricultural Economics and Farm Management, Federal University of \\ Agriculture, Abeokuta, Ogun State, Nigeria \\ *Corresponding author: Tel: 234-803-359-7423 E-mail: maolasupo@cbn.gov.ng
}

Received: November 14, 2013 Accepted: January 17, 2014 Published: February 10, 2014 doi:10.5296/rae.v6i1.4554 URL: http://dx.doi.org/10.5296/rae.v6i1.4554

\begin{abstract}
The interest drawback programme (IDP) as an innovation under the Agricultural Credit Guarantee Scheme (ACGS) was instituted to encourage loan repayment by providing a post payment rebate to loan beneficiaries that honour their loan repayment schedules coupled with the fact that it also presents a reduced effective lending rate for loans under the Scheme. Time series analysis of the operations of the IDP from 2003 till date depicted the IDP as a poor predictor of loans repayment. The long-run estimation showed that both loans guaranteed and IDP payments have been inelastic determinants of loans repaid. For every 1 million increase in loans guaranteed, loans repaid will increase by $\$ 990,000.00$, while for every $\$ 1$ million increase in IDP payment, loans repaid will reduce by $\$ 50,000.00$. This inverse relationship between loans repaid and IDP payment is contrary to a priori expectation as IDP payment was established to boost loan repayment under the ACGS. The estimation also highlighted a negative long run effect of IDP payments on loans repaid under the scheme. Though the introduction of the IDP has brought about a significant change in the series of loan repayment under the ACGS, however its long run impact on loans repayment should be addressed.
\end{abstract}

Keywords: Interest Drawback Programme; loans repayment; vector error correction model 


\section{Introduction}

Bank agricultural credit policies constitute an important source of stimulating agricultural development and a variety of policy initiatives have been channeled towards addressing the credit needs of farmers. The agricultural credit demand from commercial banks always exceeds the banks' supply irrespective of the enabling environment provided by government to bridge the yearning gap. This has compelled most farmers to turn to the next available alternatives i.e loans from money lenders and other informal sources for their credit needs (Enya and Alimba, 2008). The lending institutions have also identified the lack of "bankable" collateral security by prospective farmers and a high default rate of agricultural and small scale beneficiaries as limiting factors hindering their ability to access funds (Awoke 2004; Isiorhovoja 2013).

Olaitan (2006) reported that in a study conducted by the $\mathrm{CBN}$, shortage of primary production credit was identified as one of the major causes of declining agricultural production. This shortage was attributed to the banks reluctance to provide credit for real sector activities, especially agricultural production largely due to: inherent risks associated with agricultural production; urban/semi urban based nature and mode of operations of the banks; high cost of administration of agricultural loans and; inability of farmers to provide the necessary collateral.

The Agricultural Credit Guarantee Scheme Fund (ACGSF) was established in 1977 by the Federal Government of Nigeria (FGN) and Central Bank of Nigeria (CBN) in the ratio 60:40 with an initial Fund of $\$ 100$ million and paid up capital of $\$ 85$ million. The Scheme was designed to stimulate banks' lending to the agricultural sector by providing guarantee cover for loans advanced to the agricultural sector by banks. The guarantee pledges to pay to the lending banks, $75 \%$ of any amount net in default of outstanding balance by borrowers provided that collateral pledges had been realized and applied to the account.

Development finance professionals have advocated that credit guarantees will address difficulties facing individuals, households, farms and other small firms that wish to borrow from banks and other formal sources. The arguments in favour of their position included the facts that: guarantees can overcome collateral constraints, offset the risks of lending to SMEs and micro borrowers, address information constraints, compensate for low profit margins, modify intrinsic characteristics of small business, induce learning, and produce additionality (i.e increase access and/or reduce costs for constrained enterprises). However, the critics of the guarantee system have also outlined a number of arguments to discourage the establishment of such funds. These include: characteristics of third world banking; closed financial markets and lack of competition; capital constraints; cost of guarantees; pricing of guarantees; guarantee funds have no comparative advantage in credit assessment; banks tendency to engage in opportunistic behavior with guarantees; no additionality in guarantee schemes etc.

Since the establishment of the ACGSF in 1977, it has witnessed a variety of innovations all geared towards enhancing its efficiency and the actualization of its deliverables. The Trust 
Fund Model (TFM) and the Interest Drawback Programme (IDP) are two remarkable innovations that have stemmed out from the ACGS. The IDP was introduced in the 2003 lending season with a capital base of $\$ 2$ billion naira jointly funded by the FGN and CBN in the ratio of 60:40. The programme was conceived to reduce the effective borrowing rates of beneficiaries under the scheme after the de-regulation of the financial sector. Banks lend to borrowers at a market determined rate but borrowers benefit from a post-payment interest rebate of $40 \%$ if they repay their loans as at when due. The programme was introduced to ensure a "win-win situation" for both the farmers and the lending bank as the Central Bank ultimately encourages both parties to contribute to economic growth. Effectively, the measure was targeted at encouraging loan repayment by beneficiaries and also provides a reasonable borrowing rate for beneficiaries that are able to honour their loan repayment terms.

Quantitatively, the numbers of fully repaid loans have followed the same pattern as the numbers of guaranteed loans. Critics have argued that the interest rebate in its present application is a share misappropriation of tax payers' money to support market imperfections and further offer a soft landing to non-competitive farmers; hence a modification of the scheme is required to justify the huge expenditure and enhance service delivery. The proponents of the IDP claimed that the programme is a developmental initiative towards encouraging agricultural production and it should be seen as a social cost that should be borne by the government and other stakeholders. They also argued that the provision of post payment rebate through the IDP have improved loan repayment under the ACGS.

Both arguments are based on meaningful economic justifications and hence an impact assessment of the IDP on loan repayment under the Scheme using statistical measures will further balance the scale in favour or against the programme and justify the present implementation strategy of the programme.

\section{Research Methodology}

The basic principles of guarantee include: to influence and direct the flow of credit to any desired businesses or sector; it does not utilize funds to be given out as loans but guarantee funds are used to back loans granted by lending institutions; funds available to build up reserves to back issuance of new guarantees and; lenders are expected to shoulder risk responsibility by exercising due diligence in loans guaranteed via "risk sharing" principle. According to Nitsch and Kramer (2010), in any credit guarantee system the basic loan relationship between the borrower and the bank is extended through a third party, the guarantor. Whereas the financing (provision of funds or liquidity) remains with the bank, the credit (the trust, confidence and risk of default) is shared between the bank and the guarantor. Hence the loan relationship between the borrower and the bank is augmented to a triangular relationship in which the guarantor assumes part of the risk which would otherwise lie with the bank. 


\subsection{Contemporary Credit Guarantee Practices}

Gudger (1998), x-rayed several credit guarantee systems worldwide and gave a continental summary of the various credit guarantee systems as practiced by different countries as follows:

a. European Experience: In Western Europe, losses suffered by the guarantee funds and the amount of losses offset by the guarantee income could not be supported with credible data. With the exception of Germany, where guarantees fund operating costs are only about $1.5 \%$ of the amount of total guaranteed loans, Britain, Italy and Austria had administrative costs of $13 \%, 14 \%$ and $15 \%$ of the amounts guaranteed respectively. Guarantee schemes in Western Europe are the oldest and among the largest in the world. They are characterized by huge dependence on subsidies; they have minimal volumes in terms of operations and high operating costs that make them unlikely models for developing countries.

b. Asian Experience: The Asian guarantee market is relatively small as only a small portion of borrowers seek guarantees. This low patronage results in high administrative costs of issuing such guarantees and quite doubtful that the borrowers will be willing to incur such costs and hence Asian guarantees are also highly subsidized. An increase of 3.5\% in Japan or 7\% in Korea would be acceptable only to the most hard-pressed borrowers as the guarantee cost would exceed the interest rate currently charged on loans and double the interest rate in the countries respectively.

c. African Experience: Most African credit guarantee scheme were established with donor funds, Government funding and operating on relatively small scale. Poor performance and poor implementation have led to the untimely termination of most of these schemes, resulting from high costs and defaults. The Agricultural Credit Guarantee Scheme in Nigeria offered the single case where data are sufficient to permit close assessment as most other African guarantee systems were relatively newly established. Due to insufficient data, he roughly estimated the operational cost of the scheme to be between $13 \%$ and $15 \%$ of the amount guaranteed.

d. Latin American Experience: With a broad range of experiences from guarantee funds, the largest guarantee scheme in Latin America (FNG) is clearly a model not to be replicated in other countries. The scheme experienced low volumes of guarantees, very high operating costs, inadequate guarantee fees to meet operating costs and utilization of the income derived from earnings on capital to sustain the operation. The ACCION International model offers hope of being replicated in other regions. It offered wholesale guarantee approach which appears to have added the advantage of very low costs and a low default ratio.

\subsection{Unit Roots and Cointegration}

Stationarity properties investigation should precede any time-series econometric analysis. A stationary series revolves around a constant long-run mean and hence a finite variance that is 
independent of time. Conversely, non-stationary or unit root series rarely return to a long run deterministic path and the variance of the series are time dependent. Given the nature of that economic time-series, which are typically described as non-stationary processes, the estimates of such variables will lead to spurious regression and their economic interpretation will not be meaningful (Granger and Newbold, 1974). If data are non-stationary, they can be differenced enough to achieve stationarity. In testing for stationarity of data, the order of integration must be determined, which is usually designated as $\mathrm{I}(0), \mathrm{I}(1)$, or I(2). A stationary series is denoted by $\mathrm{I}(0)$ and a non-stationary series by $\mathrm{I}(1)$ or $\mathrm{I}(2)$ depending on the number of times a series is differenced to obtain stationarity.

Cointegration is used to determine the existence of a long-run relationship between variables. Thus, if the data sets are non-stationary at their levels but stationary at their first or second differencing, the next stage is to detect the presence of a common stochastic trend for the data series involved i.e whether the variables are cointegrated or not. According to Tijani and Ajobo (1999), cointegration analyses provides a powerful discriminating test for spurious correlation: conducting cointegration analysis between apparently correlated I(1) series and finding cointegration validates the regression. They posited that in cointegration, we also test for stationarity, but the test in applied to the residuals of the cointegration regression rather than the levels of the series.

\subsection{Vector Error Correction Models (VECM)}

VECM illuminates the understanding of the nature of any non-stationarity among different component series and can enhance longer term forecasting over an unconstrained model. A vector error correction (VEC) model is a restricted/special VAR (Vector Auto-Regressive) designed for use with non-stationary series that are stationary after differencing and known to be cointegrated. The VEC has cointegration relations built into the specification in order to restrict the long-run behavior of the endogenous variables to center around their cointegrating relationships while allowing for short-run adjustment dynamics. The cointegration term is known as the error correction term since the deviation from long-run equilibrium is corrected gradually through a series of partial short-run adjustments.

\subsection{Impulse Response}

An impulse response function shows the impact of a one-time shock to any of the innovations on current and future values of the endogenous variables. A disturbance to the series of the $i$-th variable affects the $i$-th variable and is also transmitted to all of the other endogenous variables through the dynamic (lag) structure.

\subsection{Measuring Structural Breaks in Program Evaluation}

An important way of assessing the reliability of an econometric model, especially in view of making forecasts or policy simulations, consist in checking its stability over time. Time series data can often contain structural break(s) due to a change in policy or sudden shock to the economy. Structural change is a statement about parameters and the assumption of stationarity implies that the parameters are constant over time. A structural break is said to 
have ocurred if at least one of these parameters has changed at some time (break date) in the sample period.

In the context of time-series approaches to program evaluation, pre and post program outcomes are often compared by defining a dummy for the post-program period and testing for a change in outcomes. However, the chances of having an immediate effect of the break are unlikely and hence more reasonable to give a period of time before expecting the effect of the break. Often, we focus on the simple case of an immediate structural break for simplicity and meaningful use of resources.

Chow (1960) developed one of the first testing methodologies to assess the assumption of parameter consistency. He stated that after the initial estimation of a linear regression model with $p$ coefficients, one should be able to test how well $m$ additional observations fit the regression. Chow also applied the method to test for the assumption of equality between subset of coefficients. He proposed the implementation of an F-test for the latter application and became the first to develop the distribution theory for such a test. A major limitation of the Chow Test is that the breakpoint must be known and selected a priori. Banerjee, Lumsdaine, and Stock (1992) pointed out that when the data break point is not exogenous; the conventional hypothesis testing becomes invalid. Since, the introduction of dummy variable is not in fact exogenous but data-dependent, a standard Chow test of parameter consistency is often incorrect. Quandt (1960) proposed an alternative approach, which attempts to overcome the restrictiveness of the Chow test. His approach evaluates the statistic at every possible breakpoint. However, the lack of distribution theory for the test statistics and the low computing power restricted the employment of the test.

Other tests of parameter stability include: recursive estimation test, cumulative sum (CUSUM) and Cumulative sum of square (CUSUMSQ) test, one-step ahead prediction test, Hansen's parameter stability tests and Ramsey regression equation specification Error Test (RESET).

The Chow Test will be adopted in this study due to the fact that the time of introduction of the break is known and it is logical to search for the break from the date of introduction as any search before the introduction date cannot be attributable to the program introduced.

\subsection{Empirical Evidence}

There have been research efforts at assessing loans repayment under a variety of credit programmes and also trends and achievements of the Agricultural Credit Guarantee Scheme (ACGS) have been studied but little effort has been made to assess the impact of the Interest Drawback Programme (IDP) on the ACGS. Oladeebo and Oladeebo (2008) investigated the determinants of loan repayment among smallholder farmers in Ogbomoso Agricultural zone of Oyo State and concluded that loan amount; years of farming experience with credit use and level of education positively influence loan repayment. Okon and Nkang (2009) gave an assessment of the ACGS with evidences from time series analysis and recommended that the managers of the scheme need to step up and encourage vigorous repayment of loans under the guarantee and develop capacity to process and approve guarantees and default claims on-line. Awunyo-Vitor (2012) researched into the determinants of loan repayment default 
among farmers in Ghana. He posited that farm size; engagement in off-farm income; larger loan amount; longer repayment period as well as training are variables with the likelihood of reducing loan repayment default. Isiorhovoja (2013) assessed the patterns in agricultural loans under the ACGS and recommended that the scheme should review and incorporate the lessons learnt from 1991 to 1999 into a new policy and strategy that would engender a new era of low risk of non-repayment of loans with increase in loan expansion.

\section{Data Collection Procedure}

Secondary data on the activities of the Agricultural Credit Guarantee Scheme (ACGS) from inception till date $(1978$ - 2011) were sourced from the Central Bank of Nigeria (CBN) who is the managing agent of the Scheme. Activities of the Scheme are often published in the Annual Reports of the CBN and the Bank's Statistical Bulletins. Data from all these sources were compared for consistency before their use.

\subsection{Method of Data Analysis}

\subsubsection{Test for Stationarity or Unit Root Test}

This study adopted the Augmented Dickey Fuller (ADF) and the Phillip-Peron tests statistics to verify the null hypothesis of a unit root modeled after the work of Tijani and Ajobo (1999) and Onanuga and Shittu (2010). According to Feridun,(2009), the uniform outcomes of both tests are necessary for the final conclusion about the stationarity properties of each series.

According to Greene (2003), the Dickey Fuller model could be specified as:

$$
\mathrm{X}_{\mathrm{t}}=\gamma \mathrm{X}_{\mathrm{t}-1}+\varepsilon_{\mathrm{t}}
$$

$\varepsilon_{\mathrm{t}} \sim \mathrm{N}\left[0, \sigma^{2}\right]$ and $\operatorname{Cov}\left[\varepsilon_{\mathrm{t}}, \varepsilon_{\mathrm{s}}\right]=0$ for $\mathrm{t} \neq \mathrm{s}$

Using t ratio

$$
\begin{aligned}
& \mathrm{DF}_{\mathrm{t}}=(\text { est. } \gamma-1) / \sigma_{\text {est. }} \gamma \\
& \text { Or } \mathrm{DF} \gamma=\mathrm{T}(\text { est. } \gamma-1)
\end{aligned}
$$

The Augmented Dickey Fuller (ADF) test with trend stationarity is

$$
\text { DF } \gamma=\mathrm{T}(\text { est. } \gamma-1) /\left(1-\text { est. } \gamma_{1}-\ldots . . \text { - est. } \gamma_{\mathrm{p}}\right)
$$

The advantage of this formula is that it can accommodate higher-order autoregressive process in $\varepsilon_{t}$ (Greene, 2003).

The Phillips-Peron test, termed $\mathrm{Z}$ statistics arose from their consideration of the limiting distributions of the various Dickey-Fuller statistics when the assumption that $e_{t}$ is an iid process is relaxed. They modified the ADF test as follows:

$$
\mathrm{Z} \gamma=\mathrm{T}(\mathrm{est} . \gamma-1) /\left(1-\text { est. } \gamma_{1}-\ldots . . \text { - est. } \gamma_{\mathrm{p}}\right)-(1 / 2)\left(\mathrm{T}^{2} \mathrm{~V}^{2} / \mathrm{S}^{2}\right)\left(\mathrm{a}-\mathrm{c}_{\mathrm{o}}\right)
$$

Where, $\mathrm{S}^{2}=\left(\sum \mathrm{e}_{\mathrm{i}}^{2}\right) /(\mathrm{T}-\mathrm{K}) ; \mathrm{V}^{2}=$ estimated asymptotic variance of est. $\gamma ; \mathrm{c}_{\mathrm{o}}=[(\mathrm{T}-\mathrm{K}) / \mathrm{T}] \mathrm{S}^{2}$ 
$\mathrm{a}=\mathrm{c}_{\mathrm{o}}+2 \sum_{\mathrm{j}=1}^{\mathrm{L}}[1-(\mathrm{j} / \mathrm{L}+1)] \mathrm{c}_{\mathrm{j}} ; \mathrm{c}_{\mathrm{j}} \quad=\mathrm{jth}$ autocovariance of residuals $=(1 / \mathrm{T}) \sum_{\mathrm{s}}^{\mathrm{T}} \varepsilon_{\mathrm{t}} \varepsilon_{\mathrm{t}-\mathrm{s}}$ for $\mathrm{j}=0, \ldots . ., \mathrm{p}$ and $\mathrm{s}=\mathrm{j}+1$

\subsubsection{Test for Cointegration}

According to SØrensen (2005), the best way of testing for co-integration is by using the system ML estimator of Johansen $(1992,1995)$. By definition, two series $\mathrm{y}_{\mathrm{t}}$ and $\mathrm{x}_{\mathrm{t}}$ are said to be cointegrated if there exists a parameter $\alpha$ such that the residual $\mu_{t}=y_{t}-\alpha x_{t}$ is a stationary process. Hjalmarsson and Österholm (2007) noted that Johansen's methodology started in the vector autoregression (VAR) of order $\mathrm{p}$ given by:

$$
\mathrm{y}_{\mathrm{t}}=\mu+\mathrm{A}_{1} \mathrm{y}_{\mathrm{t}-1}+\ldots+\mathrm{A}_{\mathrm{p}} \mathrm{y}_{\mathrm{t}-\mathrm{p}}+\varepsilon_{\mathrm{t}}
$$

where $y_{t}$ is a $n x 1$ vector of variables that are integrated of order one, denoted as $\mathrm{I}(1)$, and $\varepsilon_{\mathrm{t}}$ is a $n \times 1$ vector of innovations. This VAR can be re-written as:

$$
\Delta \mathrm{y}_{\mathrm{t}}=\mu+\Pi_{\mathrm{t}-1}+\sum_{i=1}^{p-1} \Gamma_{\mathrm{i}} \Delta \mathrm{y}_{\mathrm{t}-\mathrm{i}}+\varepsilon_{\mathrm{t}}
$$

where: $\Pi=\sum_{i=1}^{p} A_{\mathrm{i}}-\mathrm{I} \quad$; and

$$
\Gamma_{\mathrm{i}}=-\sum_{j=i+1}^{p} A_{\mathrm{j}}
$$

If the coefficient matrix $\Pi$ has reduced $\operatorname{rank} r<n$, then there exist nxr matrices $\alpha$ and $\beta$ each with rank $r$ such that $\Pi=\alpha \beta^{\prime}$ and $\beta^{\prime} y_{t}$ is stationary. $r$ is the number of cointegrating relationships, the elements of $\alpha$ are known as the adjustment parameters in the vector error correction model and each column $\beta$ is a cointegrating vector.

The maximum likelihood function is given as: $L^{-2 / T}{ }_{\max }(\mathrm{r})=\left|\mathrm{S}_{00}\right| \Pi_{\mathrm{i}=1}^{\mathrm{r}}\left(1-\right.$ est. $\left.\gamma_{\mathrm{i}}\right)$

Note that this is a function of the estimated eigenvalues where all the eigenvalues except the largest $r$ eigenvectors are set equal to zero. Hence, for example the test for one cointegrating vector against no cointegrating vectors consists of testing whether the largest eigenvalue is significantly different from zero.

The likelihood ratio test statistics $H$ for the hypothesis that $\Pi=\alpha \beta^{\prime}$ is of rank $r$ against the unrestricted model where $\Pi$ has full rank $\mathrm{p}$ is given as:

$$
H=-2 \ln (\mathrm{Q})=-\mathrm{T} \sum_{i=r+1}^{p} \ln \left(1-\text { est. } \lambda_{\mathrm{i}}\right)
$$

\subsubsection{VECM and Impulse Response Function}

As evidenced from the various diagnostic and specification tests, the cointegration result was estimated as a (VEC) model with one cointegration equation (CE) imposed and up to three lags allowed. This final specification served as the basis for assessing the influence of loans guaranteed and IDP payments on loans repaid under the ACGS. The relative significance of the variables to systemic shocks or innovations in any of the variable was observed using 
impulse response function.

\subsubsection{Chow Test}

Operationally, the value of loans fully repaid within a year is a function of the value of loans guaranteed within the last 2 years (since most of the guaranteed loans have maximum loan duration of 24 months), and the average lending rate by the deposit money banks (DMBs). This operational scenario will form the basis for the model formulation.

In the initial case, the single regression line is explicitly expressed as:

$$
\mathrm{LR}_{\mathrm{t}}=\mathrm{LG}_{\mathrm{t}-1}+\mathrm{LG}_{\mathrm{t}-2}+\mathrm{LenR}_{\mathrm{t}}+\mu_{\mathrm{t}}
$$

where, $L_{t}$ is the value of loans fully repaid in year $t ; \mathrm{LG}_{\mathrm{t}-1}$ is the value of guaranteed loans in year $\mathrm{t}-1$

$\mathrm{LG}_{\mathrm{t}-2}$ is the value of guaranteed loans in year $\mathrm{t}-2$; $\mathrm{LenR}_{\mathrm{t}}$ is the average lending rate by DMBs in year $\mathrm{t}$; and $\mu_{\mathrm{t}}$ is the error term in period $\mathrm{t}$.

The Chow test confirms whether the data set is best fitted by a single regression line or two separate regression lines. The structural break will be introduced in three successive years (2003 to 2005) of the introduction of the IDP.

Scenario 1(Announcement Effect): 2003 was the year of introduction of the programme, though the interest rebate was not paid that year. However, considering the announcement effect in program introduction, we will inquire the significance of that announcement on the trend of loans repaid by setting up a break point in 2003 .

Scenario 2(Operational Effect): the first IDP rebate was paid in 2004 and setting up a structural break in the year will assess the impact of IDP payment on loan repayment under the ACGS.

Scenario 3(Lag Effect): it is generally accepted in programme implementation that the effects of program introduction are not felt immediately and hence introducing a lag could give a more rational assessment of the effect of the program. Another break was set up in year 2005 to accommodate the lag period. The lag was however not accommodated beyond year 2005 so as permit the minimum number of time-series observations required to run the test.

The results from the chow test were compared with other graphical measures of structural breaks for consistency. The choice of graphical measures was informed by the fact that it does not require the specification of break dates in its analysis.

\section{Results and Discussion}

The time-series analysis of unit root tests, cointegration, VECM and impulse response were sequentially presented. Lastly, the chapter showed the results of the various tests for structural breaks. 


\subsection{Statistical Properties of the Economic Series}

\subsubsection{Unit Root Test}

The Augmented Dickey Fuller (ADF) and the Phillips-Perron tests were used to verify the presence of unit roots (stationarity) in the individual series of loans guaranteed and loans repaid under the ACGS. The number of lagged term (p) was set to be chosen automatically using the Schwarz Info Criterion (SIC) to ensure the errors are uncorrelated. The results as shown in table 1 confirmed that the variables are brought to stationarity after first differencing i.e both integrated of order $1[\mathrm{I}(1)]$ at $1 \%$ level of significance. Hence, the inclusion of both variables in classical least squares regression will most likely give spurious results (Granger and Newbold, 1974). The null hypothesis of non-stationarity $(\rho=1)$ was hence rejected at $1 \%$ significance level.

Table 1. Result of Unit Root Test in the Series of Loans Repaid and Loans Guaranteed under the ACGSF

\begin{tabular}{llllll}
\hline Variable & ADF & & \multicolumn{2}{l}{ Phillips-Perron } & Remark \\
& Statistics & \multicolumn{3}{c}{ Statistics } \\
& Test at $1^{\text {st }}$ & Test at & Test at $1^{\text {st }}$ & Test at \\
& level & difference & level & difference & \\
LNLR & 1.06 & $-4.17^{* *}$ & 1.52 & $-4.08^{* *}$ & I $(1)$ \\
LNLG & 0.86 & $-3.89^{* *}$ & 0.72 & $-3.79 * *$ & I $(1)$ \\
Critical values $@ 1 \%$ & -3.63 & -3.64 & -3.63 & -3.63 & \\
\hline
\end{tabular}

Source: Author's computation. $\quad$ ** imply significance at $1 \%$.

\subsubsection{Optimal Lag Length in VAR}

A major requirement in conducting Johansen (1992, 1995) co-integration tests and estimation of a VAR system, either in its unrestricted or restricted Vector Error Correction (VEC) forms, is the choice of an optimal lag length. This study adopted a graphical examination of the inverse roots of the AR polynomial to verify the stability of the VAR. If the estimated ARMA process is (covariance) stationary, then all AR roots should lie inside the unit circle and hence a stability of the model at that particular lag length.

Figure 1 showed the pictorial representation of the inverse roots of the AR characteristic polynomials for different lag periods and confirmed stability after allowing 3 lags in the model. 


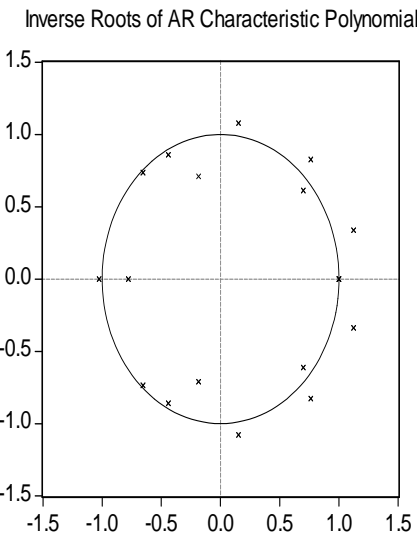

Five (5) lags

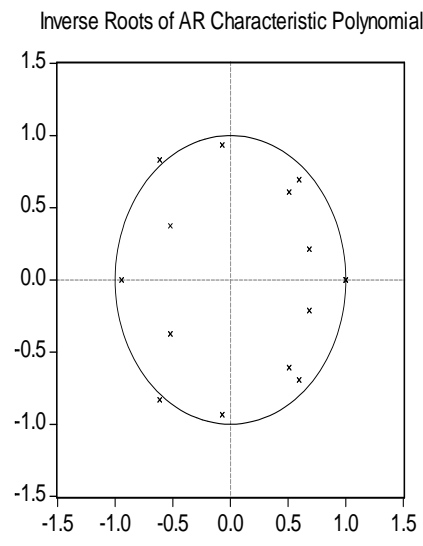

Four (4) lags

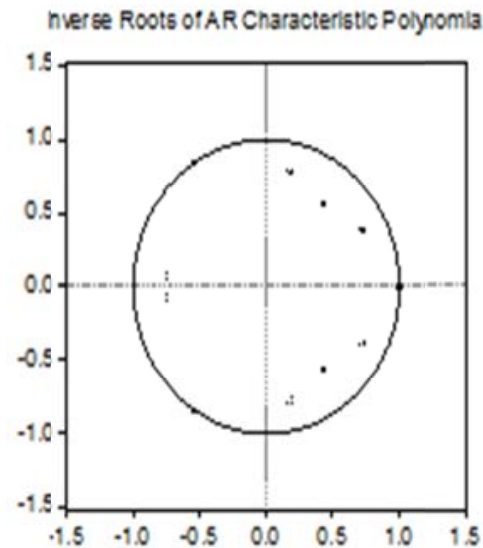

Three (3) lags

Figure 1. Inverse roots of AR characteristic polynomials associated with VAR systems with different lag structures

\subsubsection{Cointegration Test}

To ascertain the existence or otherwise of a long run relationship among the series of loans repaid, loans guaranteed and interest drawback payments, a cointegration test was performed using Johansen's ML Estimator approach. The cointegration equation was performed under the assumption of linear deterministic trend of intercept (no trend) in Cointegrating Equation (CE) and test VAR and also a lag of $(1,3)$ was selected. The trace test and the maximum Eigen value test both revealed the presence of one CE among linear combinations of loans repaid, loans guaranteed and the interest drawback payments under the ACGS at 5\% level of significance. Hence, the null hypothesis of no co-integration was rejected at $5 \%$ level of significance.

Table 2. Summary of Cointegration Results by Deterministic Specification

\begin{tabular}{rccccc}
\hline Data Trend: & None & None & Linear & Linear & Quadratic \\
\hline Test Type & No Intercept & Intercept & Intercept & Intercept & Intercept \\
& No Trend & No Trend & No Trend & Trend & Trend \\
\hline Trace & 1 & 1 & 1 & 1 & 2 \\
Max-Eig & 1 & 1 & 1 & 1 & 1 \\
\hline
\end{tabular}

Source: Author's computation. 
Table 3. Results of Cointegration Tests

\begin{tabular}{lllll}
\hline Hypothesized & Trace Test & & \multicolumn{2}{l}{ Max-Eigen value Test } \\
\hline No. of co. & Trace & $\begin{array}{l}\text { Critical value } \\
(\mathrm{p}<0.05)\end{array}$ & $\begin{array}{l}\text { Max-Eigen } \\
\text { stat }\end{array}$ & $\begin{array}{l}\text { Critical value } \\
(\mathrm{p}<0.05)\end{array}$ \\
Eqs.(CE) & stat & 29.797 & 64.437 & 21.132 \\
None** & 74.035 & 15.495 & 6.573 & 14.265 \\
At most 1 & 6.598 & 3.841 & 0.025 & 3.841 \\
At most 2 & 0.025 & . &
\end{tabular}

Source: Author's computation.

** imply significance at $1 \%$.

From the cointegration results, it can be inferred that there exists some stable long-run equilibrium relationships among the series, which could be given some error correction representations (Engle and Granger, 1987). The estimated long-run relationship (t-ratio in parenthesis), can be written as:

$$
\operatorname{lnLR}_{\mathrm{t}-1}=0.62+0.991 \operatorname{lnG}_{\mathrm{t}-1}-0.05 \operatorname{lnIDP} \mathrm{P}_{\mathrm{t}-1}
$$

The long run relationship revealed differences in the direction of influence exerted on loans repaid by loans guaranteed and IDP payments. Explicitly stated that for every $\$ 1$ million increase in loans guaranteed, loans repaid will increase by $\$ 990,000.00$, while for every $\$ 1$ million increase in IDP payment, loans repaid will reduce by $\$ 50,000.00$. This inverse relationship between loans repaid and IDP payment is contrary to a priori expectation as IDP payment was established to boost loan repayment under the ACGS. Also, given the fact that logarithmic transformed data were used, the coefficients represent elasticity and hence the long-run equation shows inelasticity i.e variations in loans guaranteed and IDP payment will produce less proportionate change in the level of loans repaid.

\subsubsection{VECM Result}

The presence of cointegration between the variables suggested a long term relationship among the variables and hence a sufficient requirement for the application of a VEC model. The F-statistics and the adjusted $\mathrm{R}^{2}$ for loans repaid and loans guaranteed are not significant and hence suggests that both variables does not significantly explain short-run changes in the model accounting for $12.44 \%$ and $(18.19 \%)$ in the two series respectively. IDP payments better explains short-run changes in the series at $\mathrm{p}<0.01$, accounting for $89.64 \%$ of the short run variations.

However, the long run relationship revealed that the effects of loans repaid on shocks that destabilize the equilibrium relationship between loans repaid and its determinants are corrected within 344 days, shocks to loans guaranteed are corrected within 299 days, while shocks to IDP payments are corrected within 24 days. From the above, it can be inferred that shocks to the series of loans repaid and its determinants under the ACGSF are all corrected within a year of occurrence. 
Table 4. Estimated Vector Error Correction Model

\begin{tabular}{llll}
\hline Error Correction & $\mathrm{D}(\mathrm{LLR})$ & $\mathrm{D}(\mathrm{LLG})$ & $\mathrm{D}(\mathrm{LIDP})$ \\
\hline ecm $(-1)$ & $-1.06(-1.81)$ & $-1.22(-1.79)$ & $-15.02(-12.37)$ \\
$\mathrm{D}(\operatorname{LLR}(-1))$ & $0.29(0.49)$ & $0.84(1.22)$ & $15.36(12.66)$ \\
$\mathrm{D}(\operatorname{LLR}(-2))$ & $0.51(0.70)$ & $1.09(1.34)$ & $15.29(10.61)$ \\
$\mathrm{D}(\operatorname{LLR}(-3))$ & $0.65(0.64)$ & $0.95(1.27)$ & $13.04(9.82)$ \\
$\mathrm{D}(\operatorname{LLG}(-1))$ & $-0.10(-0.17)$ & $-0.62(-0.92)$ & $-14.88(-12.43)$ \\
$\mathrm{D}(\operatorname{LLG}(-2))$ & $-0.38(-0.52)$ & $-1.12(-1.32)$ & $-16.00(-10.65)$ \\
$\mathrm{D}(\operatorname{LLG}(-3))$ & $-1.062(-1.44)$ & $-1.33(-1.56)$ & $-13.25(-8.73)$ \\
$\mathrm{D}(\operatorname{LIDP}(-1))$ & $0.015(0.38)$ & $0.00(0.00)$ & $-0.06(-0.71)$ \\
$\mathrm{D}(\operatorname{LIDP}(-2))$ & $-0.01(-0.28)$ & $0.02(0.44)$ & $0.13(1.62)$ \\
$\mathrm{D}($ LIDP(-3)) & $0.44(1.07)$ & $0.031(0.64)$ & $0.49(5.74)$ \\
$\mathrm{C}$ & $0.21(2.36)$ & $0.28(2.68)$ & $1.40(7.53)$ \\
Adj. R-squared & 0.12 & -0.18 & 0.90 \\
F-statistics & 1.37 & 0.60 & 23.52 \\
Log likelihood & 5.56 & 1.49 & -14.02 \\
\hline
\end{tabular}

Source: Author's computation.

Figures in parenthesis are t-values associated with the respective parameters.

\subsubsection{Impulse Response Result}

The impulse response function showed the reaction or response of each variable to a shock or stimulus in other variables in the model. The pictorial pairwise impulse analysis revealed that loans repaid responded significantly to shocks in loans guaranteed but the effect of shocks to IDP payments on loans repaid was negative and not too pronounced. This relationship between loans repaid and IDP payments was further corroborated by the minimal and negative response of IDP payments to shocks in loans repaid. 


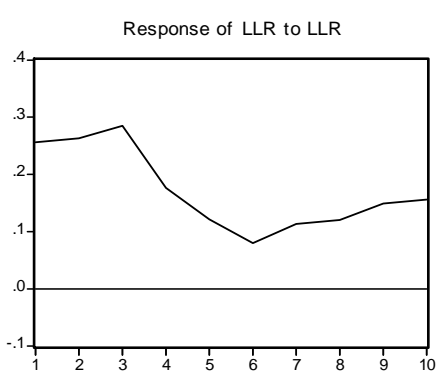

Response to Cholesky One S.D. Innovations
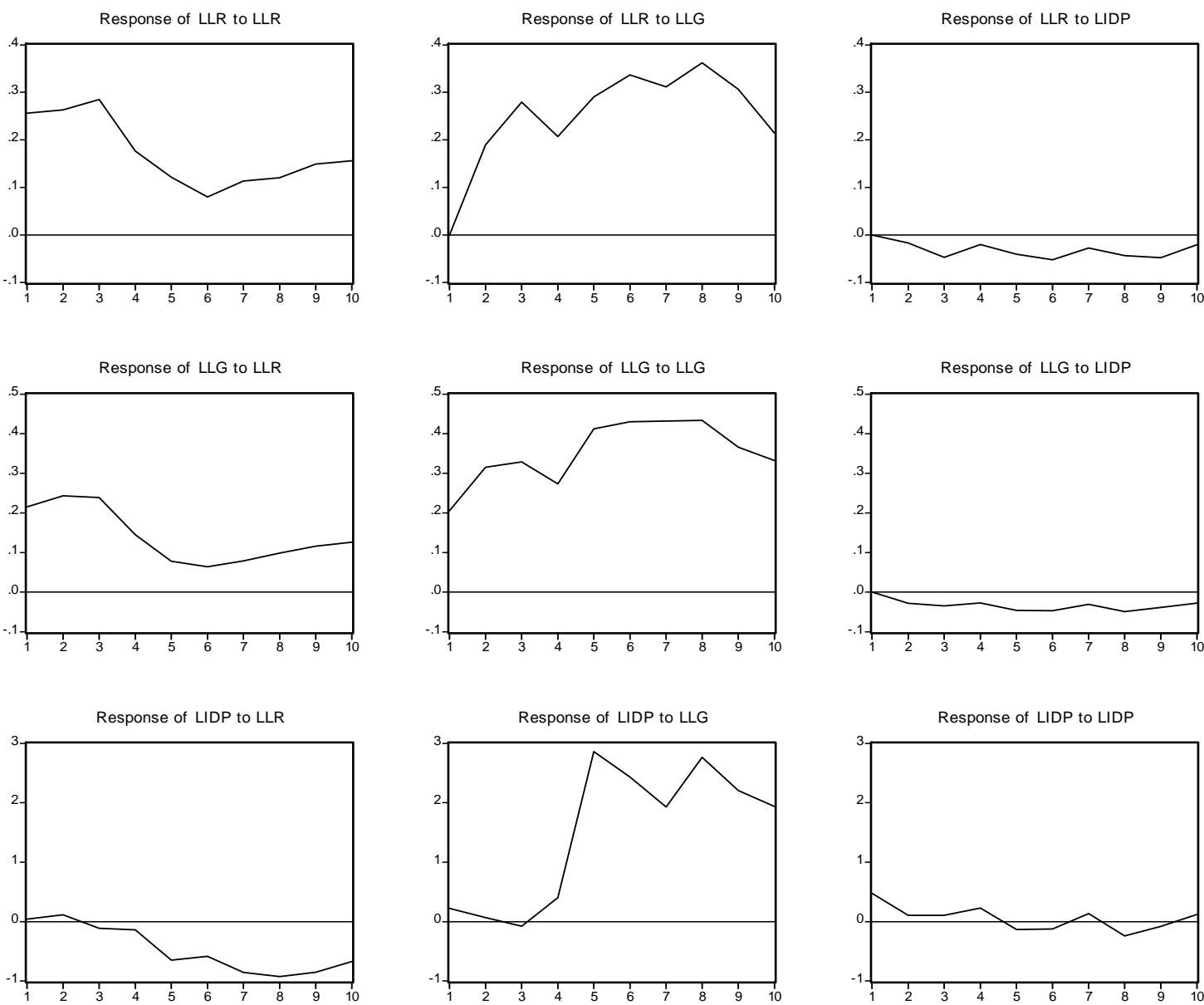

Figure 2. Impulse Response Function Graphs of Loans Repaid, Loans Guaranteed and IDP Payments

\subsection{Tests for Structural Break}

The tests for structural break were conducted to confirm if the introduction of the interest drawback programme has produced a change in the series of loans repaid under the ACGS. The chow test introduced the break in three different years to cover all possibilities surrounding the introduction of an innovation. The result of the Chow test was compared with other graphical tests of structural break for consistency.

\subsubsection{Chow Breakpoint Test Result}

The Chow test was significant at 5\%, 1\% and 1\% for breakpoint years 2003, 2004 and 2005 respectively. The null of hypothesis of no structural break was hence rejected at the 3 years. The result showed that the introduction of the IDP had effect on loans repaid under the ACGS. The result also showed that the significance of the test statistic kept getting stronger as the operations of the scheme was getting more prominent thereby signifying greater impact of IDP on loans repaid with time. 
Table 5. Result of Chow Test for Breakpoints in Years: 2003, 2004 and 2005

\begin{tabular}{lll}
\hline Breakpoint & F-statistic & Probability \\
\hline 2003 & 3.702425 & 0.018119 \\
2004 & 6.072982 & 0.001734 \\
2005 & 71.01295 & 0.000000 \\
\hline
\end{tabular}

Source: Author's computation.

The other graphical tests of structural breaks used were the CUSUM test, CUSUM square test, $\mathrm{N}$-step probability test and the One-step ahead probability test. The graphical tests construct a series within defined boundaries and attribute deviations outside the boundaries to the existence of a structural break. The significance of their use was based on the fact that they do not require the specification of a breakpoint in their analysis but rather search for a breakpoint along the entire data series. However, the major setback of these methods being that breaks identified before the implementation of a programme cannot be attributed to that programme.

\subsubsection{Graphical Tests for Structural Break}

The CUSUM test identified no structural break in the series of loans guaranteed at $5 \%$ level of significance. The CUSUM Square test showed the presence of structural break in the series of loans repaid but the break cannot really be attributed to the introduction of the IDP as it started before its introduction. The N-step and One-step ahead probability tests both confirmed the existence of structural break in the series of loans guaranteed and the break is more prominent after the introduction of the IDP and also becomes more prominent with continued implementation of the IDP.

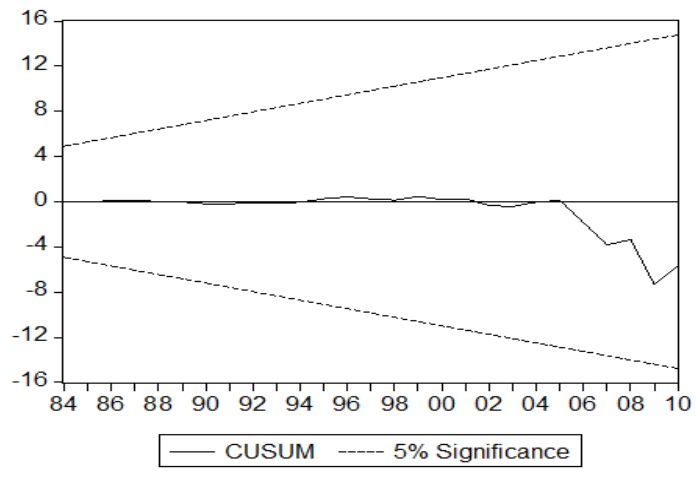

Figure 3. Result of CUSUM test

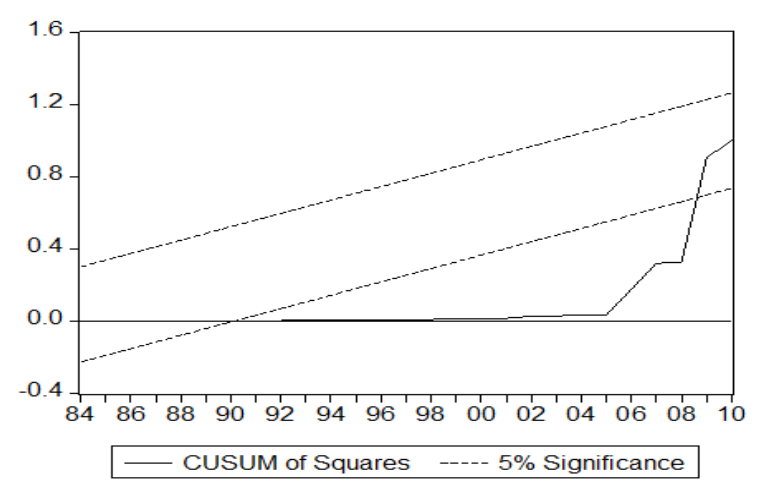

Figure 4. Result of CUSUM Square test 


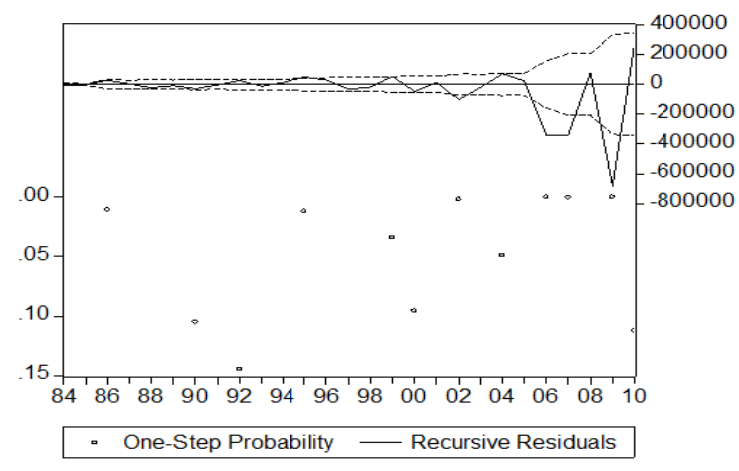

Figure 5. Result of One-Step Ahead Probability test

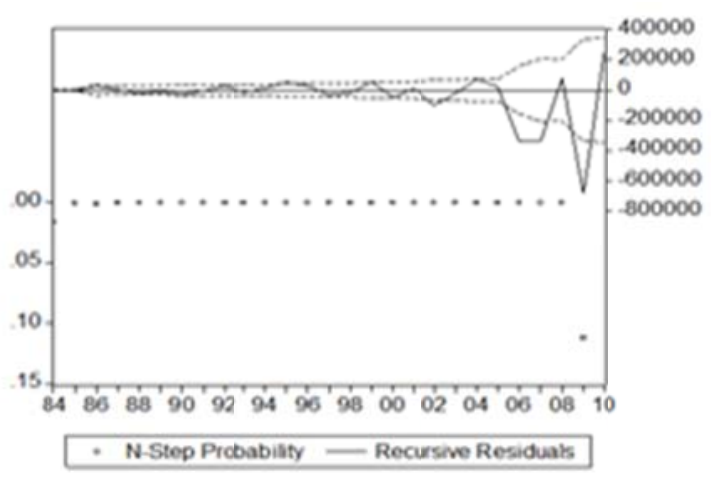

Figure 6. Result of N-Step Probability test

\section{Summary, Conclusion and Recommendation}

This study examined the activities of the Agricultural Credit Guarantee Scheme (ACGS) within the context of a time series analysis. The presence or otherwise of unit roots in the series of loans guaranteed and loans repaid were examined using the Augmented Dickey Fuller and Phillips-Perron tests. The Johansen ML estimator was used for the cointegration test and the existence of cointegration in the series of the variables was further explored to estimate a long-run relationship for the variables and ultimately dovetailed in the estimation of a VECM. Impulse response function was used to measure the impact of shocks in individual variable on other variables in the series. The Chow test was used to test for the existence of a structural break in loans repaid since the introduction of the IDP under the ACGS. The study concluded by using other measures of structural breaks to corroborate the findings of the Chow test.

The study revealed a steady growth in the operations of the ACGS culminating in maximum annual loans guaranteed and loans repaid of $\$ 10.189$ billion and $\$ 7.186$ billion respectively since the commence of the scheme. The ADF and PP tests both confirmed the series of loans guaranteed and loans repaid under the ACGS to be integrated of order 1 at $1 \%$ level of significance. The Johansen method of cointegration using both the trace test and the maximum Eigen value test revealed the existence of one cointegrating equation (CE) among the variables, which further pointed to the existence of a long-run relationship among the variables. The long-run estimation showed that both loans guaranteed and IDP payments are inelastic determinants of loans repaid as a $1 \%$ change in both variables will produce a less proportionate change in the levels of loans repaid. The estimation also highlighted a negative long run effect of IDP payments on loans repaid under the scheme. Though the magnitude is small but the long-run effect contradicts the expectation or the policy thrust on the introduction of the IDP, which was to encourage loan repayment. The magnitude of this adverse effect might become more prominent with time. The vecm revealed that adjustments were attained within a year for shocks to loans repaid and loans guaranteed while adjustments to shocks to IDP are corrected with a month. This minimal effect of the IDP as a determinant of loan repayment was further buttressed by the impulse response function which showed that shocks to the IDP payment series has minimal effect on loan repayment. It can be concluded 
from the tests for structural breaks that the introduction of the IDP had caused a structural break in the series of loans guaranteed under the scheme and the graphical measures of structural break showed that the impact was getting better over time, hence a justification of the introduction of the IDP as an innovation under the ACGS.

Based on the above submissions, the following recommendations were made:

1. The introduction of the IDP as an innovation under the ACGS has caused a change in the loan repayment pattern but the IDP is a weak predictor of loan repayment and hence it has not significantly boosted loan repayment under the ACGS. The CBN should consider other innovations that can effectively enhance loan repayment under the ACGS.

2. The IDP poses a negative effect on loan repayment in the long-run though the effect is marginal. This negative long-run effect calls for caution and the need to take proactive measures by the administrators of the scheme. The CBN should review the modalities for the IDP programme as it has the potential of contradicting the policy objective of loan repayment under the ACGS.

\section{References}

Awoke, M.U. (2004). Factors Affecting Loan Acquisition and Repayment Pattern of Small Holder Farmers in Ika North East of Delta State, Nigeria. J. Sustainable Trop. Agric Res, 9, 61-64.

Banerjee, A., Lumsdaine, R.L., \& Stock, J.H. (1992). Recursive and Sequential Test of the Unit Root and Trend-Break Hypothesis: Theory and International Evidence. Journal of Business and Economic Statistics, 10, 271-287.

Central Bank of Nigeria: Annual Reports and Statement of Accounts. (Several editions).

Central Bank of Nigeria (2010). Statistical Bulletin.

Central Bank of Nigeria (2011). Agricultural Credit Guarantee Scheme Funds Statistics.

Chow, G.C. (1960). Test of Equality between Sets of Coefficients in Two Linear Regressions. Econometrica, 28, 591-605. http://dx.doi.org/10.2307/1910133

Awunyo-Vitor, D. (2012). Determinants of Loan Repayment Default among Farmers in Ghana. Journal of Development and Agricultural Economics, 4(13), 339-345.

Enya, V.E, \& Alimba, J.O. (2008). Analysis of Factors Affecting the Supply of Commercial Banks Credit to the Agricultural Sector in Nigeria (1986-2005). Continental J. Agricultural Economics, 2, 74-77.

Feridun, M. (2009). "Unit Roots, Structural Breaks and Cointegration Analysis: A review of the Available Processes and Procedures and an Application". Presented at the Macroeconomics and Financial Economics Workshop, held from October $8^{\text {th }}$ to $9^{\text {th }}$ at 
East Mediterranean University).

Granger, C.W.J., \& Newbold, P. (1974). Spurious Regressions in Econometrics. Journal of Econometrics, 2, 110-120. http://dx.doi.org/10.1016/0304-4076(74)90034-7

Green, W.H. (2003). Econometric Analysis(Fourth Edition.). Prentice Hall, Upper Saddle River, New Jersey.

Gudger, M. (1998). "Credit Guarantees: An Assessment of the State of Knowledge and new avenues of Research". FAO Agricultural Services Bulletin, 129.

Hjalmarsson, E., \& Österholm, P. (2007). "Testing for Cointegration Using the Johansen Methodology when Variables are Near-Integrated” International Monetary Fund (IMF) Working Paper (WP/07/141).

Isiorhovoja, R.A. (2013). Patterns in Agricultural Loans under the Agricultural Credit Guarantee Scheme in Nigeria. Meditterranean Journal of Social Sciences, 4(1), 497-502. http://dx.doi.org/10.5901/mjss.2013.v4n1p497

Johansen, S. (1992). Determination of Cointegration Rank in the Presence of a Linear Trend. $\begin{array}{lllll}\text { Oxford Bull. } & \text { Econ. }\end{array}$ http://dx.doi.org/10.1111/j.1468-0084.1992.tb00008.x

Johansen, S. (1995). Likelihood-based Inference in Cointegrated Vector Autoregressive Models. Oxford University Press, UK. http://dx.doi.org/10.1093/0198774508.001.0001

Nitsch, M., \& Kramer, D. (2010). Credit Guarantee Systems for Small Enterprises Under Scrutiny: The Case of the German Buergschaftsbanken. Rev. Adm. Publica, 44, 4.

Okon, X.A., \& Nkang, N.M. (2009). An Assessment of Nigeria's Agricultural Credit Guarantee Scheme Fund: Evidence from Time-series Analysis. Global Journal of Agricultural Sciences, 8(2), 133-145.

Oladeebo, J.O., \& Oladeebo, O.E. (2008). Determinants of Loan Repayment among Smallholder Farmers I Ogbomoso Agricultural Zone of Oyo State, Nigeria. J. Soc. Sci., 17(1), 59-62.

Olaitan, M.A. (2006). Finance for Small and Medium Enterprises: Nigeria's Agricultural Credit Guarantee Scheme Fund. Journal of International Farm Management, 3(2), 1-9.

Onanuga, A.T., \& Shittu, A.M. (2010). Determinants of Interest Rates in Nigeria: An Error Correction Model. Journal of Economics and International Finance, 2(12), 261-271.

Quandt, R. (1960). Tests of the Hypothesis that a Linear Regression Obeys Two Separate Regimes. Journal of the American Statistical Association, 55, 324-330. http://dx.doi.org/10.1080/01621459.1960.10482067

SØrensen, B.E. (2005). Cointegration. http://www.uh.edu/ bsorense/coint.pdf Accessed on $12 / 11 / 12$. 
Tijani, A.A., \& Ajobo, O. (1999). Productivity-Export Relationship in Nigeria’s Agriculture. The Indian Journal of Economics, LXXIX(314), 323-332.

\section{Copyright Disclaimer}

Copyright reserved by the author(s).

This article is an open-access article distributed under the terms and conditions of the Creative Commons Attribution license (http://creativecommons.org/licenses/by/3.0/). 